\title{
Analisis Materi Ajar Kimia SMA/MA Kelas XI Pada Konsep Termokimia
}

\author{
Gusmilasari*, Abdul Hadjranul Fatah, Maya Erliza Anggraeni \\ Program Studi Pendidikan Kimia, Jurusan Pendidikan MIPA, Fakultas Keguruan \\ dan Ilmu Pendidikan, Universitas Palangka Raya, Indonesia \\ email: gusmilasari97@gmail.com
}

Diterima: 05 Maret 2020; Disetujui: 20 Maret 2020; Diterbitkan: 28 Maret 2020

\begin{abstract}
ABSTRAK
Penelitian ini bertujuan untuk mendeskripsikan kesesuaian konsep termokimia pada materi ajar kimia SMA/MA Kelas XI terhadap kurikulum 2013 dan mendeskripsikan struktur makro wacana dan proposisi yang berpotensi kesalahan konsep. Instrumen yang digunakan yaitu tabel identifikasi label konsep dan proposisi mikro-makro, model struktur makro wacana, dan tabel identifikasi proposisi yang berpotensi kesalahan konsep. Data dianalisis secara deskriptif. Hasil penelitian menunjukkan bahwa label konsep yang sama terdapat pada buku teks A maupun buku teks B berjumlah 22 yang sesuai dengan kurikulum 2013. Label konsep yang sesuai dengan kurikulum 2013 pada buku teks A dan buku teks B masing-masing berjumlah 15 label konsep dan 13 label konsep. Struktur makro wacana pada buku teks A pembahasan konsep pada dimensi elaborasi mencapai level 5 dan dimensi progresi pada level 2 terdapat 6 konsep, sedangkan pada buku teks B pembahasan konsep pada dimensi elaborasi mencapai level 6 dan dimensi progresi pada level 2 terdapat 4 konsep.
\end{abstract}

Kata Kunci: buku teks, konsep, label, termokimia

\section{PENDAHULUAN}

Ilmu kimia merupakan ilmu yang mempelajari tentang struktur susunan, sifat, dan perubahan materi serta energi yang menyertai perubahan materi tersebut. Menurut Arifin (2007) mengemukakan bahwa kimia sebagai salah satu bidang ilmu dalam Ilmu Pengetahuan Alam (IPA), seperti halnya pada ilmu yang lain terbentuk dari fakta, konsep, prinsip, teori, dan hukum yang termasuk pengetahuan deklaratif dan cara bagaimana pengetahuan itu terbentuk yang dikelompokkan dalam prosedural. Pengetahuan prosedural sejajar dengan berpikir tingkat tinggi (Asi, 2018). Pengetahuan itu terbangun dari konsepkonsep, pengetahuan tertentu yang memiliki bentuk organisasi konsep struktur tertentu dengan sifatnya yang berbeda.

Pemahaman konsep yang tidak benar secara terus menerus dapat mengakibatkan miskonsepsi pada peserta didik. Kesalahan konsep pada kimia merupakan suatu hal yang berlanjut dan dapat menghambat peserta didik mengaitkan antara konsep yang satu dengan konsep lainnya. Kesulitan pada suatu materi yang dialami siswa dipengaruhi oleh beberapa faktor seperti sumber belajar, guru, dan siswa yang bersangkutan.

Termokimia merupakan salah satu materi yang ada dalam kurikulum kimia SMA/MA kelas XI IPA. Konsep termokimia mempelajari tentang perubahan entalpi dan persamaan termokimia. Salah satu materi termokimia yang dianggap 
sulit adalah konsep hukum Hess, seperti yang diungkapkan Agustin (2017) bahwa sebagian besar siswa kelas XI IPA SMA Negeri Kota Palangka Raya mengalami kesulitan dalam memahami konsep penentuan perubahan entalpi ditinjau dari hukum Hess.

Kesulitan-kesulitan yang dialami siswa bukan hanya dipengaruhi oleh proses belajar, tetapi juga dapat dipengaruhi oleh buku teks yang digunakan. Keberadaan buku pelajaran memang membantu sebagai salah satu sumber belajar bagi siswa namun tak jarang pula menimbulkan miskonsepsi apabila siswa salah mengintepretasikannya. Oleh karena itu, diperlukan analisis terlebih dahulu terhadap buku teks pelajaran, termasuk pelajaran kimia (Wiguna, 2014).

Menurut Arifin (2008) analisis wacana dilakukan dengan analisis teks dasar. Analisis dilakukan melalui proses yang dibagi ke dalam tiga tahap, yaitu pembentukan teks dasar atau penghalusan dasar teks, penurunan proposisi mikro dan makro, serta penyusunan struktur makro. Penurunan struktur makro ini dihasilkan dari pemetaan proposisi mikro dan proposisi makro dengan menjaga hubungan hirarkinya antara materi subyek dan tindakan yang menyertainya. Seperti yang dijelaskan Vitriani (2012) pemetaan ini dimulai dengan menulis topik wacana. Topik diuraikan menjadi proposisi makro 1 (P-I), (P-II), (P-III), dan (P-IV), proposisi ini mempunyai tingkat abstraksi tertinggi.

Struktur makro dibentuk dengan menggunakan dasar dimensi progresi dan elaborasi. Dimensi progresi (vertikal) menyangkut tindakan makro yang diterapkan dalam rangka mewujudkan tujuan dari suatu wacana atau membentuk suatu struktur wacana atau kedalaman materi subyek. Dimensi elaborasi (horizontal) menyangkut tindakan makro menurut organisasi tema dari suatu wacana, sehingga membentuk struktur materi atau keluasan materi subyek.

Materi pembelajaran kimia pada buku teks A maupun buku teks B disesuaikan berdasarkan silabus kurikulum 2013. Silabus mata pelajaran kimia adalah rencana pembelajaran pada mata pelajaran kimia yang mencakup kompetensi inti, kompetensi dasar, materi pokok/pembelajaran, kegiatan pembelajaran, indikator pencapaian kompetensi untuk penilaian, penilaian, alokasi waktu, dan sumber belajar.

Rumusan masalah berdasarkan latar belakang tersebut adalah bagaimana kesesuaian konsep termokimia pada materi ajar kimia SMA/MA Kelas XI terhadap kurikulum 2013, bagaimana struktur makro wacana dalam materi ajar kimia SMA/MA Kelas XI pada konsep termokimia, dan proposisi apa saja yang berpotensi kesalahan konsep yang terdapat dalam materi ajar kimia SMA/MA Kelas XI pada konsep termokimia. Berdasarkan uraian tersebut, maka penulis perlu mengkaji tentang "Analisis Materi Ajar Kimia SMA/MA Kelas XI Pada Konsep Termokimia" agar potensi kesalahan konsep (miskonsepsi) yang ditimbulkan oleh buku teks dapat diminimalisir.

\section{METODOLOGI PENELITIAN}

Penelitian ini menggunakan metode penelitian deskriptif yang bertujuan untuk mendeskripsikan fenomena-fenomena yang ada. Hal yang dideskripsikan dalam penelitian ini adalah hasil analisis konsep materi termokimia dalam buku kimia SMA/MA kelas XI. Waktu pengumpulan data dimulai pada bulan Februari 2019 dan objek penelitian adalah dua buku SMA/MA berdasarkan kurikulum 2013 yang disajikan pada tabel 1 . 
Tabel 1. Buku Teks Termokimia

\begin{tabular}{|c|c|c|c|c|c|}
\hline No. & Judul & Penulis & Penerbit & $\begin{array}{c}\text { Tempat dan } \\
\text { Tahun Terbit }\end{array}$ & $\begin{array}{l}\text { Kode } \\
\text { Buku }\end{array}$ \\
\hline 1. & $\begin{array}{l}\text { Buku Teks Kimia } \\
\text { untuk SMA/MA } \\
\text { Kelas XI }\end{array}$ & $\begin{array}{l}\text { Unggul } \\
\text { Sudarmo dan } \\
\text { Nanik } \\
\text { Mitayani }\end{array}$ & Erlangga & Surakarta, 2013 & A \\
\hline 2. & $\begin{array}{l}\text { Buku Teks Kimia } \\
\text { untuk SMA/MA } \\
\text { Kelas XI }\end{array}$ & $\begin{array}{l}\text { Erfan } \\
\text { Priyambodo } \\
\text { dkk }\end{array}$ & $\begin{array}{l}\text { PT Intan } \\
\text { Pariwara }\end{array}$ & Jakarta, 2016 & B \\
\hline
\end{tabular}

Data penelitian ini berupa konsep termokimia yang terdapat pada buku teks A dan buku teks B yang dikumpulkan melalui lembar observasi berupa teks asli, teks dasar, dan teks asli yang berpotensi kesalahan konsep (miskonsepsi). Langkah-langkah pengumpulan data yaitu, sebagai berikut:

Tabel 2. Langkah-Langkah Pengumpulan Data

\begin{tabular}{|c|c|c|}
\hline $\begin{array}{c}\text { Data yang } \\
\text { Dikumpulkan }\end{array}$ & Teknik Pengumpulan Data & Instrumen \\
\hline $\begin{array}{l}\text { - Teks Asli } \\
\text { - Teks Dasar }\end{array}$ & $\begin{array}{l}\text { 1. Teks asli diambil dari masing- } \\
\text { masing materi ajar dengan cara } \\
\text { discan menggunakan printer dan } \\
\text { diketik pada program microsoft } \\
\text { word } \\
\text { 2. Teks asli yang discan atau } \\
\text { diketik berupa konsep materi } \\
\text { termokimia } \\
\text { 3. Teks asli dimasukan kedalam } \\
\text { tabel pembentukan teks dasar, dalam } \\
\text { pembentukkan teks dasar dilakukan } \\
\text { proses penghalusan melalui } \\
\text { penghapusan dan penyisipan kata } \\
\text { 4. Teks asli diidentifikasi dengan } \\
\text { menggunakan tabel identifikasi pada } \\
\text { tabel } 6\end{array}$ & $\begin{array}{l}\text { Lembar observasi } \\
\text { dalam bentuk tabel } \\
\text { identifikasi } \\
\text { relevansi teks asli } \\
\text { dengan label }\end{array}$ \\
\hline $\begin{array}{ll}\text { - } & \text { Teks asli } \\
\text { - } & \text { Teks asli yang } \\
\text { berpotensi } \\
\text { kesalahan } \\
\text { konsep }\end{array}$ & $\begin{array}{l}\text { 1. Teks asli (konsep termokimia } \\
\text { dan contoh soal) pada materi } \\
\text { termokimia ditelaah secara cermat } \\
\text { 2. Setelah ditelaah secara } \\
\text { keseluruhan pada teks asli dapat } \\
\text { ditemukan proposisi yang berpotensi } \\
\text { kesalahan konsep } \\
\text { 3. Teks asli yang berpotensi } \\
\text { kesalahan konsep discan atau } \\
\text { diketik pada program microsoft } \\
\text { word } \text { Proposisi yang berpotensi } \\
\text { 4. kesalahan konsep }\end{array}$ & $\begin{array}{l}\text { Lembar observasi } \\
\text { dalam bentuk tabel } \\
\text { identifikasi } \\
\text { proposisi yang } \\
\text { berpotensi } \\
\text { kesalahan konsep } \\
\text { (miskonsepsi) }\end{array}$ \\
\hline
\end{tabular}




\begin{tabular}{ccc}
\hline $\begin{array}{c}\text { Data yang } \\
\text { Dikumpulkan }\end{array}$ & \multicolumn{1}{c}{ Teknik Pengumpulan Data } & Instrumen \\
\hline & $\begin{array}{l}\text { diidentifikasidengan menggunakan } \\
\text { tabel identifikasi pada tabel 8 yang } \\
\text { memuat konsepsi peneliti }\end{array}$ \\
\hline
\end{tabular}

Data yang diperoleh pada lembar observasi dianalisis dengan langkahlangkah sebagai berikut:

Tabel 3. Langkah-Langkah Analisis Data

Data yang
dianalisis

\begin{tabular}{|c|c|}
\hline - Teks Dasar & $\begin{array}{l}\text { 1. Teks dasar yang diperoleh dimasukkan ke dalam tabel } 7 \\
\text { penurunan proposisi mikro dan makro yang melalui } \\
\text { proses penghapusan, generalisasi, dan konstruksi dengan } \\
\text { menyalin (copy-paste) pada program microsoft word } \\
\text { 2. Pada proses penghapusan dilakukan untuk } \\
\text { menghilangkan kata-kata yang tidak diperlukan sehingga } \\
\text { akan menghasilkan proposisi mikro dan makro } \\
\text { 3. Pada proses generalisasi dapat diturunkan dari proposisi } \\
\text { tertentu sehingga dihasilkan proposisi makro yang } \\
\text { bersifat umum } \\
\text { 4. Pada proses konstruksi dapat dihasilkan proposisi baru, } \\
\text { yaitu proposisi makro dibangun dari beberapa proposisi } \\
\text { mikro } \\
\text { 5. Label konsep (proposisi makro) yang didapatkan } \\
\text { disesuaikan terhadap kurikulum } 2013 \\
\text { 6. Proposisi makro yang dihasilkan akan dilakukan } \\
\text { pemetaan ke dalam struktur makro wacana }\end{array}$ \\
\hline $\begin{array}{l}\text { Teks asli yang } \\
\text { berpotensi } \\
\text { kesalahan konsep } \\
\text { (miskonsepsi) }\end{array}$ & $\begin{array}{l}\text { Teks asli yang berpotensi kesalahan konsep dilakukan } \\
\text { analisis dengan cara memberikan konsepsi peneliti, } \\
\text { menunjukkan teks yang berpotensi kesalahan konsep, } \\
\text { dan alasan penentuan teks yang berpotensi kesalahan } \\
\text { konsep (miskonsepsi) }\end{array}$ \\
\hline
\end{tabular}

\section{HASIL PENELITIAN DAN PEMBAHASAN}

Konsep termokimia pada buku teks A dibahas pada bab 2 halaman 56-92. Analisis konsep dilakukan pada keseluruhan materi termokimia. Berikut ini akan dijelaskan mengenai hasil dan pembahasan dari analisis konsep yang meliputi relevansi antara teks asli dengan label konsep serta jenis pengetahuan pada buku teks A.

Tabel 4. Cuplikan Hasil Identifikasi Label Konsep dan Jenis Pengetahuan Berdasarkan Teks Dasar pada Buku Teks A

\begin{tabular}{ccccc}
\hline No. & Teks Dasar & $\begin{array}{c}\text { Label } \\
\text { Konsep }\end{array}$ & $\begin{array}{c}\text { Jenis } \\
\text { Pengetahua } \\
\text { n }\end{array}$ & Halaman \\
\hline $1 . \quad$ Ada dua hal yang harus diperhatikan & Sistem & Konseptual & 101 \\
\hline
\end{tabular}




\begin{tabular}{ll}
\hline dalam termokimia berkaitan dengan & Lingkungan \\
perpindahan energi, yaitu sistem dan & Faktual \\
lingkungan. Segala sesuatu yang & \\
menjadi pusat perhatian dalam & \\
mempelajari perubahan energi disebut & \\
sistem, sedangkan hal-hal di luar & \\
sistem yang membatasi sistem dan & \\
dapat memengaruhi sistem disebut & \\
lingkungan. & \\
& Reaksi antara larutan NaOH dengan \\
larutan HCl dalam tabung reaksi, & \\
terjadi kenaikan suhu yang & \\
menyebabkan suhu tabung reaksi naik, & \\
demikian juga dengan suhu di & \\
sekitarnya. & \\
Larutan NaOH dan larutan HCl & \\
merupakan pusat perhatian (sistem) & \\
pada contoh tersebut, sedangkan & \\
tabung reaksi, suhu udara, tekanan & \\
udara merupakan lingkungan. & \\
\hline
\end{tabular}

Label konsep yang dibahas pada tabel 4 yaitu sistem dan lingkungan termasuk ke dalam jenis pengetahuan konseptual, berupa pengertian sistem dan lingkungan, serta label konsep tersebut juga memiliki jenis pengetahuan faktual yang memiliki ciri-ciri ditampilkan simbol-simbol atau label berupa contoh yang disertai dengan penulisan contoh senyawa kimia dan benda-benda yang digunakan.

Konsep termokimia pada buku teks B dibahas pada bab 3 halaman 51-80. Analisis konsep dilakukan pada keseluruhan materi termokimia. Berikut ini akan dijelaskan mengenai hasil dan pembahasan dari analisis konsep yang meliputi relevansi antara teks asli dengan label konsep serta jenis pengetahuan pada buku B

Tabel 5. Cuplikan Hasil Identifikasi Label Konsep dan Jenis Pengetahuan Berdasarkan Teks Dasar pada Buku Teks B

\begin{tabular}{|c|c|c|c|c|}
\hline No. & Teks Dasar & Label Konsep & $\begin{array}{c}\text { Jenis } \\
\text { Pengetahuan }\end{array}$ & Halaman \\
\hline 1. & $\begin{array}{l}\text { Reaksi eksoterm juga terjadi } \\
\text { pada proses pembakaran kayu. } \\
\text { Apa yang kalian rasakan jika } \\
\text { duduk di sekeliling api unggun } \\
\text { saat berkemah? Badan akan } \\
\text { merasa hangat dari api unggun, } \\
\text { bukan? Reaksi kimia sering } \\
\text { menimbulkan perubahan suhu, } \\
\text { baik kenaikan maupun penurunan. } \\
\text { Contohnya, reaksi saat pemakaian } \\
\text { koyo dan pembakaran kayu bakar }\end{array}$ & Termokimia & $\begin{array}{l}\text { Metakognitif } \\
\text { Faktual } \\
\text { Konseptual }\end{array}$ & 129 \\
\hline
\end{tabular}




\begin{tabular}{|c|c|c|c|c|}
\hline No. & Teks Dasar & Label Konsep & $\begin{array}{c}\text { Jenis } \\
\text { Pengetahuan }\end{array}$ & Halaman \\
\hline & $\begin{array}{l}\text { pada api unggun menghasilkan } \\
\text { kenaikan suhu. Sebaliknya, reaksi } \\
\text { antara Kalsium Hidroksida } \\
\left(\mathrm{Ca}(\mathrm{OH})_{2}\right) \text { dan Ammonium } \\
\mathrm{Klorida}\left(\mathrm{NH}_{4} \mathrm{Cl}\right) \text { menghasilkan } \\
\text { penurunan suhu. Cabang ilmu } \\
\text { kimia yang mempelajari kalor } \\
\text { reaksi kimia disebut termokimia. }\end{array}$ & & & \\
\hline
\end{tabular}

Label konsep pertama pada tabel 5 yaitu termokimia termasuk jenis pengetahuan metakognitif berupa pertanyaan mengenai reaksi eksoterm dan endoterm yang dihubungkan dengan kehidupan sehari-hari, jenis pengetahuan faktual berupa contoh mengenai reaksi eksoterm dan endoterm yang berkaitan dengan kehidupan sehari-hari dan adanya penulisan simbol berupa senyawa kimia, dan jenis pengetahuan konseptual berupa pengertian termokimia.

Perbandingan label konsep buku teks A dan buku teks B dapat dicermati dengan tabel 6 berikut ini.

Tabel 6. Perbandingan Label Konsep Buku Teks A dan Buku Teks B

\begin{tabular}{|c|c|c|c|c|c|}
\hline No & Label Konsep & $\begin{array}{c}\text { Buku Teks } \\
\text { A }\end{array}$ & Halaman & $\begin{array}{c}\text { Buku Teks } \\
\text { B }\end{array}$ & Halaman \\
\hline & Termokimia & $\sqrt{ }$ & 103 & $\sqrt{ }$ & 131 \\
\hline 2. & Energi & & & $\sqrt{ }$ & 133 \\
\hline 3. & Bentuk-bentuk energi & & & $\sqrt{ }$ & 133 \\
\hline 4. & Termodinamika & & & $\sqrt{ }$ & 135 \\
\hline 5. & Hukum I Termodinamika & & & $\sqrt{ }$ & 135 \\
\hline 6. & Sistem & $\sqrt{ }$ & 104 & $\sqrt{ }$ & 137 \\
\hline 7. & Lingkungan & $\sqrt{ }$ & 104 & $\sqrt{ }$ & 137 \\
\hline & Ienis-ienis system & $\sqrt{ }$ & 105 & & \\
\hline & utan tabel 6 juka & $\sqrt{ }$ & 106 & $\sqrt{ }$ & 138 \\
\hline 10. & Sistem tertutup & $\sqrt{ }$ & 106 & $\sqrt{ }$ & 138 \\
\hline & Sistem terisolasi & $\sqrt{ }$ & 106 & $\sqrt{ }$ & 138 \\
\hline 12. & Kerja & $\sqrt{ }$ & 106 & & \\
\hline & Energi dalam $(U)$ & $\sqrt{ }$ & 106 & $\sqrt{ }$ & 136 \\
\hline 14. & Persamaan energi dalam & $\sqrt{ }$ & 107 & & \\
\hline & Perubahan energi dalam $(\Delta U)$ & $\sqrt{ }$ & 107 & $\sqrt{ }$ & 137 \\
\hline 16. & $\begin{array}{l}\text { Persamaan perubahan energi } \\
\text { dalam }\end{array}$ & $\sqrt{ }$ & 108 & & \\
\hline & Kalor & & & $\sqrt{ }$ & 137 \\
\hline & Rumus kalor system & $\sqrt{ }$ & 110 & & \\
\hline 19. & Rumus kerja system & $\sqrt{ }$ & 110 & & \\
\hline 20. & Entalpi $(H)$ & $\sqrt{ }$ & 111 & $\sqrt{ }$ & 139 \\
\hline 21. & Perubahan entalpi $(\Delta H)$ & $\sqrt{ }$ & 112 & & \\
\hline 22. & Reaksi eksoterm & $\sqrt{ }$ & 114 & $\sqrt{ }$ & 139 \\
\hline 23. & Reaksi endoterm & $\sqrt{ }$ & 115 & $\sqrt{ }$ & 140 \\
\hline 24. & Grafik entalpi & & & $\sqrt{ }$ & 142 \\
\hline
\end{tabular}




\begin{tabular}{|c|c|c|c|c|c|}
\hline No & Label Konsep & $\begin{array}{c}\text { Buku Teks } \\
\text { A }\end{array}$ & Halaman & $\begin{array}{l}\text { Buku Teks } \\
\text { B }\end{array}$ & Halaman \\
\hline 25. & Energi pengaktifan $\left(\mathrm{E}_{\mathrm{a}}\right)$ & & & $\sqrt{ }$ & 142 \\
\hline 26. & Asas Black & & & $\sqrt{ }$ & 143 \\
\hline 27. & Persamaan termokimia & $\sqrt{ }$ & 116 & $\sqrt{ }$ & 143 \\
\hline 28. & $\begin{array}{l}\text { Pedoman dalam penulisan } \\
\text { persamaan termokimia }\end{array}$ & & & $\sqrt{ }$ & 145 \\
\hline 29. & $\begin{array}{l}\text { Diagram energi pembentukan } \\
\text { air }\end{array}$ & $\sqrt{ }$ & 118 & & \\
\hline 30. & $\begin{array}{l}\text { Diagram energi proses } \\
\text { penguapan air }\end{array}$ & $\sqrt{ }$ & 119 & & \\
\hline 31. & $\begin{array}{l}\text { Perubahan entalpi standar } \\
\left(\Delta H^{\circ}\right)\end{array}$ & $\sqrt{ }$ & 119 & $\sqrt{ }$ & 146 \\
\hline 32. & $\begin{array}{l}\text { Perubahan entalpi } \\
\text { pembentukan standar }\left(\Delta H_{\mathrm{f}}^{\circ}\right)\end{array}$ & $\sqrt{ }$ & 120 & $\sqrt{ }$ & 147 \\
\hline 33. & $\begin{array}{l}\text { Perubahan entalpi penguraian } \\
\text { standar }\left(\Delta H_{\mathrm{d}}^{\circ}\right)\end{array}$ & $\sqrt{ }$ & 121 & $\sqrt{ }$ & 147 \\
\hline 34. & $\begin{array}{l}\text { Perubahan entalpi pembakaran } \\
\text { standar }\left(\Delta H_{\mathrm{c}}^{\circ}\right)\end{array}$ & $\sqrt{ }$ & 113 & $\sqrt{ }$ & 148 \\
\hline 35. & $\begin{array}{l}\text { Perubahan entalpi netralisasi } \\
\text { standar }\left(\Delta H_{\mathrm{n}}^{\circ}\right)\end{array}$ & & & $\sqrt{ }$ & 148 \\
\hline 36. & $\begin{array}{l}\text { Perubahan entalpi penguapan } \\
\text { standar }\left(\Delta H_{\text {vap }}^{\circ}\right)\end{array}$ & & & $\sqrt{ }$ & 149 \\
\hline 37. & $\begin{array}{l}\text { Metode penentuan perubahan } \\
\text { entalpi }\end{array}$ & & & $\sqrt{ }$ & 149 \\
\hline 38. & Kalorimeter & & & $\sqrt{ }$ & 150 \\
\hline 39. & Kalorimeter sederhana & $\sqrt{ }$ & 122 & & \\
\hline 40. & $\begin{array}{l}\text { Perhitungan jumlah kalor atau } \\
\text { persamaan kalor reaksi }\end{array}$ & $\sqrt{ }$ & 122 & $\sqrt{ }$ & 150 \\
\hline 41. & Kalorimeter bom & $\sqrt{ }$ & 123 & $\sqrt{ }$ & 151 \\
\hline 42. & Kapasitas kalor kalorimeter & $\sqrt{ }$ & 124 & $\sqrt{ }$ & 151 \\
\hline 43. & Hukum Hess & $\sqrt{ }$ & 125 & $\sqrt{ }$ & 152 \\
\hline 44. & $\begin{array}{l}\text { Perubahan entalpi berdasarkan } \\
\text { selisih entalpi pembentukan }\end{array}$ & & & $\sqrt{ }$ & 154 \\
\hline 45. & $\begin{array}{l}\text { Pemutusan dan penggabungan } \\
\text { ikatan }\end{array}$ & $\sqrt{ }$ & 126 & & \\
\hline 46. & Energi ikatan & $\sqrt{ }$ & 127 & $\sqrt{ }$ & 155 \\
\hline 47. & Energi disosiasi ikatan & $\sqrt{ }$ & 127 & & \\
\hline 48. & Energi ikatan rata-rata & $\sqrt{ }$ & 127 & & \\
\hline 49. & $\begin{array}{l}\text { Rumus }(\Delta H) \text { menggunakan } \\
\text { energi ikatan rata-rata }\end{array}$ & $\sqrt{ }$ & 128 & $\sqrt{ }$ & 155 \\
\hline 50. & Pembakaran & & & $\sqrt{ }$ & 155 \\
\hline 51. & Jenis reaksi pembakaran & & & $\sqrt{ }$ & 158 \\
\hline 52. & Bahan bakar & $\sqrt{ }$ & 129 & & \\
\hline 53. & Nilai kalor bakar & $\sqrt{ }$ & 129 & & \\
\hline
\end{tabular}

Keterangan: 


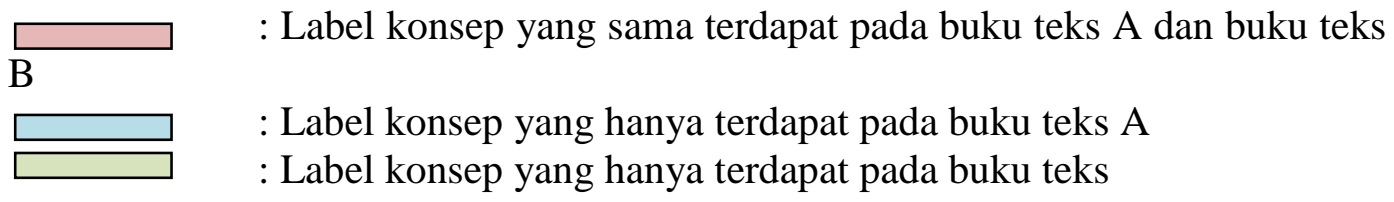

Label konsep termokimia yang terdapat pada buku teks A maupun buku teks B dianalisis kesesuaian dengan silabus mata pelajaran kimia kurikulum 2013. Hasil analisis kesesuaian ditampilkan pada tabel 7.

Tabel 7. Kesesuaian Label Konsep Buku Teks A dan Buku Teks B Terhadap Kurikulum 2013

\begin{tabular}{|c|c|c|c|c|c|c|}
\hline \multirow{3}{*}{$\begin{array}{c}\text { Kode } \\
\text { Kompetensi Dasar } \\
\text { (KD) }\end{array}$} & \multirow{3}{*}{$\begin{array}{c}\text { Kode } \\
\text { Materi Pokok } \\
\text { (MP) }\end{array}$} & \multirow{3}{*}{ Label Konsep } & \multicolumn{4}{|c|}{$\begin{array}{c}\text { Kesesuaian dengan } \\
\text { Silabus }\end{array}$} \\
\hline & & & \multicolumn{2}{|c|}{ KD } & \multicolumn{2}{|c|}{ MP } \\
\hline & & & $\begin{array}{c}\text { Buk } \\
\text { u A }\end{array}$ & $\begin{array}{l}\text { Buk } \\
\text { u B }\end{array}$ & $\begin{array}{c}\text { Buk } \\
\text { uA }\end{array}$ & $\begin{array}{c}\text { Buk } \\
\text { uB }\end{array}$ \\
\hline \multirow{6}{*}{$\begin{array}{l}3.4 \quad \text { Menjelaskan } \\
\text { konsep perubahan } \\
\text { entalpi reaksi pada } \\
\text { tekanan tetap dalam } \\
\text { persamaan } \\
\text { termokimia }\end{array}$} & a. Sistem dan & Termokimia & $*$ & $*$ & $*$ & $*$ \\
\hline & lingkungan & Sistem & 3.4 & 3.4 & $\mathrm{a}$ & $\mathrm{a}$ \\
\hline & b. Reaksi & Lingkungan & 3.4 & 3.4 & $\mathrm{a}$ & $\mathrm{a}$ \\
\hline & eksoterm dan & Sistem terbuka & 3.4 & 3.4 & $\mathrm{a}$ & $\mathrm{a}$ \\
\hline & reaksi & Sistem tertutup & 3.4 & 3.4 & $\mathrm{a}$ & $\mathrm{a}$ \\
\hline & endoterm & Sistem terisolasi & 3.4 & 3.4 & $\mathrm{a}$ & $\mathrm{a}$ \\
\hline \multirow{4}{*}{$\begin{array}{l}3.5 \quad \text { Menjelaskan } \\
\text { jenis entalpi reaksi, } \\
\text { hukum Hess, dan } \\
\text { konsep energi } \\
\text { ikatan }\end{array}$} & c. Diagram & Energi dalam $(U)$ & 3.4 & 3.4 & $\mathrm{a}$ & $\mathrm{a}$ \\
\hline & $\begin{array}{l}\text { tingkat dan } \\
\text { diagram }\end{array}$ & $\begin{array}{l}\text { Perubahan energi } \\
\text { dalam }(\Delta U)\end{array}$ & 3.4 & 3.4 & $\mathrm{a}$ & $\mathrm{a}$ \\
\hline & siklus & Entalpi & 3.4 & 3.4 & d & d \\
\hline & d. Perubahan & Reaksi eksoterm & 3.4 & 3.4 & $\mathrm{~b}$ & $\mathrm{~b}$ \\
\hline \multirow{12}{*}{$\begin{array}{l}4.4 \quad \text { Menyimpulka } \\
\mathrm{n} \text { hasil analisis data } \\
\text { percobaan } \\
\text { termokimia pada } \\
\text { tekanan tetap } \\
\text { 4.5 Membandingkan } \\
\text { perubahan entalpi } \\
\text { beberapa reaksi } \\
\text { berdasarkan data } \\
\text { hasil percobaan }\end{array}$} & entalpi & Reaksi endoterm & 3.4 & 3.4 & $\mathrm{~b}$ & $\mathrm{~b}$ \\
\hline & berbagai & $\begin{array}{l}\text { Perubahan entalpi } \\
\text { standar }\left(\Delta H^{\circ}\right)\end{array}$ & 3.4 & 3.4 & $\mathrm{~d}$ & d \\
\hline & $\begin{array}{l}\text { reaksi }\left(\Delta H^{\circ}\right. \\
) \text { pembentuka }\end{array}$ & Perubahan entalpi & 34 & 34 & $d$ & $d$ \\
\hline & & $\operatorname{standar}\left(\Delta H_{\mathrm{f}}^{\circ}\right)$ & & 3.4 & $\mathrm{~d}$ & d \\
\hline & $\begin{array}{l}\Delta H^{\circ} \\
\text { pembakaran, } \\
\Delta H^{\circ}\end{array}$ & $\begin{array}{l}\text { Perubahan entalpi } \\
\text { peruraian standar } \\
\left(\Delta H_{\mathrm{d}}^{\circ}\right)\end{array}$ & 3.4 & 3.4 & d & d \\
\hline & $\begin{array}{l}\text { pelarutan, } \\
\text { dan } \Delta H^{\circ} \\
\text { netralisasi) }\end{array}$ & $\begin{array}{l}\text { Perubahan entalpi } \\
\text { pembakaran } \\
\text { standar }\left(\Delta H_{\mathrm{c}}^{\circ}\right)\end{array}$ & 3.4 & 3.4 & d & $\mathrm{d}$ \\
\hline & $\begin{array}{l}\text { e. Kalorimeter } \\
\text { f. Hukum Hess }\end{array}$ & $\begin{array}{l}\text { Persamaan } \\
\text { termokimia }\end{array}$ & 3.4 & 3.4 & $\mathrm{~d}$ & d \\
\hline & $\begin{array}{l}\text { g. Energi ikatan } \\
\text { h. Kalor }\end{array}$ & $\begin{array}{l}\text { Persamaan kalor } \\
\text { reaksi }\end{array}$ & 4.5 & 4.5 & $\mathrm{e}$ & $\mathrm{e}$ \\
\hline & pembakaran & $\begin{array}{l}\text { Kapasitas kalor } \\
\text { kalorimeter }\end{array}$ & 4.5 & 4.5 & e & e \\
\hline & & Kalorimeter bom & 4.5 & 4.5 & $\mathrm{e}$ & $\mathrm{e}$ \\
\hline & & Hukum Hess & 3.5 & 3.5 & $\mathrm{f}$ & $\mathrm{f}$ \\
\hline & & Energi ikatan & 3.5 & 3.5 & $\mathrm{~g}$ & $\mathrm{~g}$ \\
\hline
\end{tabular}




\begin{tabular}{|c|c|c|c|c|c|c|}
\hline \multirow{4}{*}{$\begin{array}{c}\text { Kode } \\
\text { Kompetensi Dasar } \\
\text { (KD) }\end{array}$} & \multirow{4}{*}{$\begin{array}{c}\text { Kode } \\
\text { Materi Pokok } \\
\text { (MP) }\end{array}$} & \multirow{3}{*}{ Label Konsep } & \multicolumn{4}{|c|}{$\begin{array}{c}\text { Kesesuaian dengan } \\
\text { Silabus }\end{array}$} \\
\hline & & & \multicolumn{2}{|c|}{ KD } & \multicolumn{2}{|c|}{ MP } \\
\hline & & & $\begin{array}{l}\text { Buk } \\
\text { u A }\end{array}$ & $\begin{array}{l}\text { Buk } \\
\text { u B }\end{array}$ & $\begin{array}{c}\text { Buk } \\
\text { uA }\end{array}$ & $\begin{array}{c}\text { Buk } \\
\text { uB }\end{array}$ \\
\hline & & $\begin{array}{l}\text { Rumus }(\Delta H) \\
\text { menggunakan } \\
\text { energi ikatan rata- } \\
\text { rata }\end{array}$ & 3.5 & 3.5 & $\mathrm{~g}$ & $\mathrm{~g}$ \\
\hline & & Jenis-jenis sistem & 3.4 & - & $\mathrm{a}$ & - \\
\hline & & Kerja & 3.4 & - & $\mathrm{a}$ & - \\
\hline & & $\begin{array}{l}\text { Persamaan energi } \\
\text { dalam }\end{array}$ & 3.4 & - & $\mathrm{a}$ & - \\
\hline & & $\begin{array}{l}\text { Persamaan } \\
\text { perubahan energi } \\
\text { dalam }\end{array}$ & 3.4 & - & $\mathrm{a}$ & - \\
\hline & & Rumus kalor sistem & 3.4 & - & $\mathrm{a}$ & - \\
\hline & & Rumus kerja sistem & 3.4 & - & $\mathrm{a}$ & - \\
\hline & & $\begin{array}{l}\text { Perubahan entalpi } \\
(\Delta H)\end{array}$ & 3.4 & - & $\mathrm{d}$ & - \\
\hline & & $\begin{array}{l}\text { Diagram energi } \\
\text { pembentukan air }\end{array}$ & 3.4 & - & $\mathrm{b}$ & - \\
\hline & & $\begin{array}{l}\text { Diagram energi } \\
\text { proses penguapan } \\
\text { air }\end{array}$ & 3.4 & - & $\mathrm{b}$ & - \\
\hline & & $\begin{array}{l}\text { Kalorimeter } \\
\text { sederhana }\end{array}$ & 4.5 & - & $\mathrm{e}$ & - \\
\hline & & $\begin{array}{l}\text { Pemutusan dan } \\
\text { penggabungan } \\
\text { ikatan }\end{array}$ & 3.5 & - & $\mathrm{g}$ & - \\
\hline & & $\begin{array}{l}\text { Energi disosiasi } \\
\text { ikatan }\end{array}$ & 3.5 & - & $\mathrm{g}$ & - \\
\hline & & $\begin{array}{l}\text { Energi ikatan rata- } \\
\text { rata }\end{array}$ & 3.5 & - & $\mathrm{g}$ & - \\
\hline & & Bahan bakar & 4.5 & - & $\mathrm{h}$ & - \\
\hline & & Nilai kalor bakar & 4.5 & - & $\mathrm{h}$ & - \\
\hline & & Energi & - & 3.4 & - & $\mathrm{b}$ \\
\hline & & $\begin{array}{l}\text { Bentuk-bentuk } \\
\text { energi }\end{array}$ & - & 3.4 & - & $\mathrm{b}$ \\
\hline & & Termodinamika & - & - & - & - \\
\hline & & $\begin{array}{l}\text { Hukum I } \\
\text { termodinamika }\end{array}$ & - & - & - & - \\
\hline & & Kalor & - & 3.4 & - & $\mathrm{b}$ \\
\hline & & Grafik entalpi & - & 3.4 & - & $\mathrm{b}$ \\
\hline & & $\begin{array}{l}\text { Energi pengaktifan } \\
\left(E_{a}\right)\end{array}$ & - & 3.4 & - & $\mathrm{b}$ \\
\hline & & Asas Black & - & - & - & - \\
\hline
\end{tabular}




\begin{tabular}{|c|c|c|c|c|c|c|}
\hline \multirow{11}{*}{$\begin{array}{c}\text { Kode } \\
\text { Kompetensi Dasar } \\
\text { (KD) }\end{array}$} & \multirow{3}{*}{$\begin{array}{c}\text { Kode } \\
\text { Materi Pokok } \\
\text { (MP) }\end{array}$} & \multirow{3}{*}{ Label Konsep } & \multicolumn{4}{|c|}{$\begin{array}{c}\begin{array}{c}\text { Kesesuaian dengan } \\
\text { Silabus }\end{array} \\
\end{array}$} \\
\hline & & & \multicolumn{2}{|c|}{ KD } & \multicolumn{2}{|c|}{ MP } \\
\hline & & & $\begin{array}{c}\text { Buk } \\
\text { u A }\end{array}$ & $\begin{array}{c}\text { Buk } \\
\text { u B }\end{array}$ & $\begin{array}{c}\text { Buk } \\
\text { uA }\end{array}$ & $\begin{array}{c}\text { Buk } \\
\text { uB }\end{array}$ \\
\hline & & $\begin{array}{l}\text { Pedoman dalam } \\
\text { penulisan } \\
\text { persamaan } \\
\text { termokimia }\end{array}$ & - & 3.4 & - & d \\
\hline & & $\begin{array}{l}\text { Perubahan entalpi } \\
\text { netralisasi standar } \\
\left(\Delta H_{\mathrm{n}}^{\circ}\right)\end{array}$ & - & 3.4 & - & d \\
\hline & & $\begin{array}{l}\text { Perubahan entalpi } \\
\text { penguapan standar } \\
\left(\Delta H_{\mathrm{vap}}^{\circ}\right)\end{array}$ & - & 3.4 & - & $\mathrm{d}$ \\
\hline & & $\begin{array}{l}\text { Metode penentuan } \\
\text { perubahan entalpi }\end{array}$ & - & $\begin{array}{c}3.5 \\
\& \\
4.5\end{array}$ & - & $e, f, g$ \\
\hline & & Kalorimeter & - & 4.5 & - & $\mathrm{e}$ \\
\hline & & $\begin{array}{l}\text { Perubahan entalpi } \\
\text { berdasarkan selisih } \\
\text { entalpi } \\
\text { pembentukan }\end{array}$ & - & 3.5 & - & $\mathrm{f}$ \\
\hline & & Pembakaran & - & 4.5 & - & $\mathrm{h}$ \\
\hline & & $\begin{array}{l}\text { Jenis reaksi } \\
\text { pembakaran }\end{array}$ & - & 4.5 & - & $\mathrm{h}$ \\
\hline
\end{tabular}

Keterangan:

$\mathrm{B}$

: Label konsep yang sama terdapat pada buku teks A dan buku teks

: Label konsep yang hanya terdapat pada buku teks A

$\begin{array}{ll}\text { Tanda } * & \text { : Label konsep yang hanya terdapat pada buku teks B } \\ \text { Lonsep sesuai dengan keseluruhan KD dan MP }\end{array}$

Tanda (-) : Tidak ada label konsep

Berdasarkan tabel 7 di atas menunjukkan bahwa kesesuaian label konsep terhadap kurikulum 2013, yang mana terbagi menjadi tiga warna diantaranya merah yaitu warna yang menunjukkan bahwa label konsep yang sama terdapat pada buku teks A dan buku teks B yang berjumlah 22 label konsep. Setelah dianalisis, ternyata label konsep yang ditandai dengan warna merah semua sudah sesuai dengan KD dan MP pada silabus kurikulum 2013. Contohnya pada label konsep perubahan entalpi standar $\left(\Delta H^{\circ}\right)$ yang sesuai dengan KD 3.4 yaitu menjelaskan konsep perubahan entalpi reaksi pada tekanan tetap dalam persamaan termokimia. Label Konsep ini juga termasuk ke dalam materi pokok (MP) d yaitu perubahan entalpi standar untuk berbagai reaksi $\left(\Delta H^{\circ}\right)$.

Warna yang kedua adalah warna biru yang menunjukkan bahwa label konsep hanya terdapat pada buku teks A yang berjumlah 15 label konsep dan 
semua label konsep sesuai dengan silabus kurikulum 2013. Contohnya pada label konsep energi ikatan rata-rata yang sesuai dengan KD 3.5 yaitu menjelaskan jenis entalpi reaksi, hukum Hess, dan konsep energi ikatan. Label konsep ini merujuk pada materi pokok (MP) g yaitu energi ikatan.

Warna yang ketiga adalah warna hijau yang menunjukkan bahwa label konsep hanya terdapat pada buku teks B yang berjumlah 16 label konsep, tetapi hanya 13 label konsep yang sesuai dengan silabus kurikulum 2013. Salah satu contohnya adalah kalorimeter yang sesuai dengan KD 4.5 yaitu membandingkan perubahan entalpi beberapa reaksi berdasarkan data hasil percobaan. Label konsep ini merujuk pada materi pokok (MP) e yaitu kalorimeter.

Penyesuaian label konsep terhadap kurikulum 2013 tersebut dilakukan agar materi yang terdapat pada buku teks A maupun buku teks B tidak hanya materi yang dituliskan tanpa adanya rujukan seperti silabus kurikulum 2013 (K-13) dan dengan adanya kesesuaian tersebut tujuan pembelajaran akan tercapai, serta siswa mampu memahami konsep termokimia dengan baik sehingga mendapatkan nilai yang memuaskan. Berdasarkan tabel 14 diketahui bahwa label konsep yang sesuai terhadap silabus K-13 lebih banyak terdapat pada buku teks A dibandingkan dengan buku teks B, tetapi terdapat beberapa label konsep pada buku teks B yang tidak ada pada buku teks A maupun sebaliknya. Oleh karena itu, kedua buku tersebut dapat digunakan secara bersamaan dalam proses pembelajaran.

Label konsep yang didapatkan dari pembentukan teks dasar serta penurunan proposisi mikro-makro, selanjutnya dilakukan pemetaan proposisi mikro dan proposisi makro dengan menjaga hubungan hierarkinya antara materi subyek dan tindakan yang menyertainya melalui struktur makro wacana. Struktur makro wacana buku teks A disajikan pada bagan 1 (lampiran). Struktur makro dibentuk dengan menggunakan dasar progresi dan dimensi elaborasi. Susunan konsep termokimia pada teks A dengan pembahasan konsep pada dimensi elaborasi (kedalaman materi) mencapai level 5 dan dimensi progresi (cakupan materi) mencapai 6 konsep pada level 2.

Pada buku teks B, khususnya pada label konsep Termodinamika dan Hukum I Termodinamika tidak dipetakan ke dalam strukur makro wacana, hal ini dikarenakan label konsep tersebut hanya digunakan sebagai pengantar materi pembelajaran pada konsep termokimia. Struktur makro wacana buku teks B disajikan pada bagan 2 (lampiran). Struktur makro dibentuk dengan menggunakan dasar dimensi progresi dan dimensi elaborasi. Susunan konsep termokimia pada buku teks B dengan pembahasan konsep pada dimensi elaborasi (kedalaman materi) mencapai level 6 dan dimensi progresi (cakupan materi) mencapai 4 konsep pada level 2.

Buku teks A mempunyai beberapa proposisi baik dari segi bahasa maupun contoh soal yang disajikan buku yang dapat berpotensi kesalahan konsep (miskonsepsi). Salah satunya adalah proposisi perubahan entalpi peruraian standar $\left(\Delta H_{\mathrm{d}}^{\circ}\right)$ mengandung konsep yang berpotensi miskonsepsi, tepatnya pada contoh soal. Pada contoh soal dituliskan bahwa perubahan entalpi pembentukan standar dengan notasi $\Delta H_{\mathrm{f}}^{\circ} \mathrm{H}_{2} \mathrm{O}=-240 \mathrm{~kJ}$, maka perubahan entalpi peruraian standar ditulis dengan notasi $\Delta H_{\mathrm{d}} \mathrm{H}_{2} \mathrm{O}=+240 \mathrm{~kJ} \mathrm{~mol}^{-1}$. Penulisan notasi untuk perubahan entalpi peruraian standar adalah $\left(\Delta H_{\mathrm{d}}^{\circ}\right)$ atau menggunakan notasi $\left(\Delta H_{\mathrm{d}}\right)$ dapat membuat siswa kebingungan sehingga hal ini mengakibatkan terjadi miskonsepsi, jika sebelumnya guru belum menjelaskan secara mendalam mengenai materi 
tersebut. Proposisi yang berpotensi kesalahan konsep terletak pada penulisan notasi yang mana disajikan dalam gambar 1 .

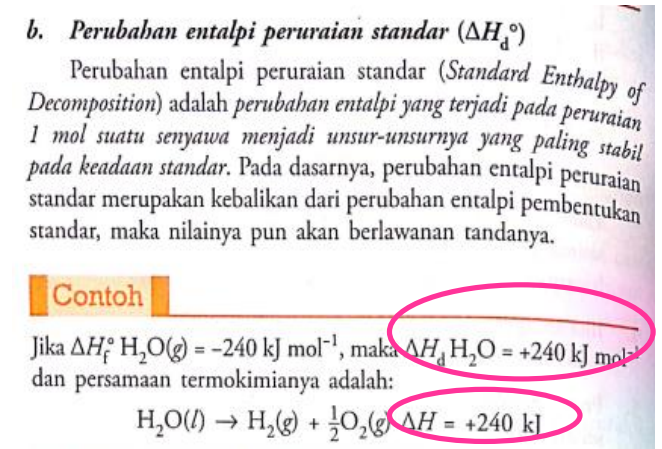

Gambar 1. Potensi kesalahan konsep 1

Pada dasarnya, perubahan entalpi peruraian standar kebalikan dari perubahan entalpi pembentukan standar (Atkins, 1994: 56). Jika $\Delta H_{\mathrm{f}}^{\circ} \mathrm{H}_{2} \mathrm{O}=-240$ $\mathrm{kJ} \mathrm{mol}^{-1}$, maka $\Delta H_{\mathrm{d}}^{\circ} \mathrm{H}_{2} \mathrm{O}=+240 \mathrm{~kJ} \mathrm{~mol}^{-1}$. Dapat dicermati dari penulisan notasi tersebut, contoh tidak menuliskan untuk peruraian diminta dalam keadaan standar atau tidak. Sebenarnya sudah dijelaskan bahwa $\Delta H_{\mathrm{f}}^{\circ}$ kebalikan dari $\Delta H_{\mathrm{d}}^{\circ}$. Contoh tersebut menuliskan untuk pembentukan dilakukan dalam keadaan standar, maka untuk peruraian juga dilakukan dalam keadaan standar dengan notasi $\Delta H_{\mathrm{d}}^{\circ}$.

Beberapa contoh soal pada buku teks A tidak menuliskan satuan, hal tersebut juga dapat menyebabkan miskonsepsi, seperti yang disajikan pada gambar 2 .

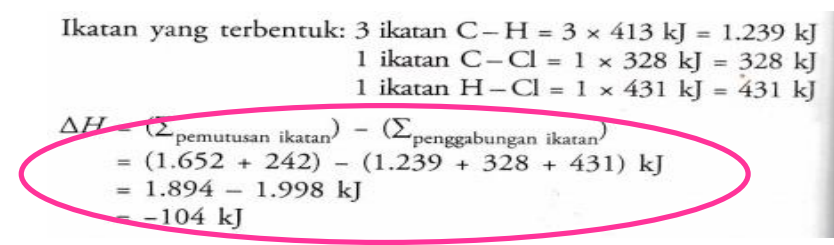

Gambar 2. Potensi kesalahan konsep 2

Buku teks B mempunyai beberapa konsep baik dari segi bahasa maupun contoh soal yang disajikan buku yang dapat berpotensi kesalahan konsep (miskonsepsi). Salah satunya adalah beberapa contoh soal yang tidak memuat rumus terlebih dahulu dan tidak mencantumkan satuan. Contoh soal yang membahas mengenai perubahan entalpi pembentukan standar terdapat pada halaman 61 paragraf 1, perubahan entalpi pembakaran standar halaman 61 paragraf 2, kalorimeter bom halaman 65-66 potensi kesalahan yang terdapat adalah tidak adanya rumus yang ditulis terlebih dahulu dalam penyelesaian jawaban contoh soal.

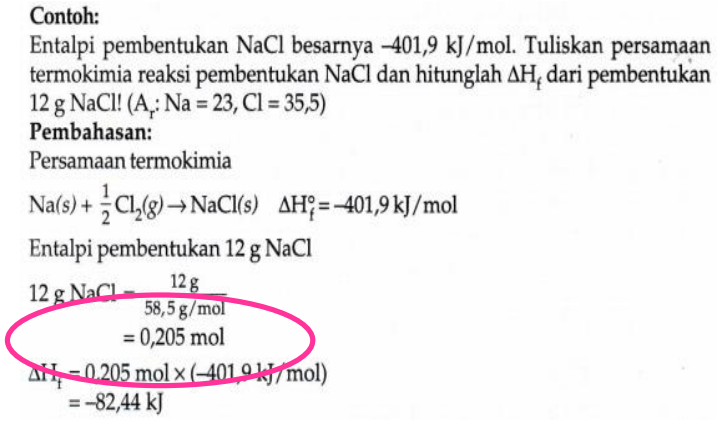

Gambar 3. Potensi kesalahan konsep 3 
Pada contoh soal yang ditulis, penulis langsung memasukan nilai kedalam rumus untuk mencari mol dan contoh soal juga mengandung konsep prasyarat yang salah yaitu tentang konsep yang menunjukkan atribut ukuran yaitu g (ukuran massa), dalam rumus mol (n). Begitu juga untuk satuan $(\mathrm{g} / \mathrm{mol})$ kemungkinan besar siswa tidak tahu bahwa satuan tersebut digunakan untuk massa molar (sama dengan massa molekul relatif (Mr), untuk menghindari miskonsepsi maka penulisan yang tepat adalah dengan menuliskan rumus terlebih dahulu, yaitu:

dengan:

$$
\text { massa }=\mathrm{n} \times \mathrm{Mm} \text { atau } \mathrm{n}=\frac{\text { massa }(\mathrm{g})}{\operatorname{Mm}\left(\frac{\mathrm{g}}{\mathrm{mol}}\right)}
$$

$\mathrm{m}=\operatorname{massa}(\mathrm{g})$

$\mathrm{n}=$ jumlah $\mathrm{mol}(\mathrm{mol})$

$\mathrm{Mm}=$ massa molar $(\mathrm{g} / \mathrm{mol})$

Massa molar $(\mathrm{Mm})$ senyawa $=$ Mr senyawa $(\mathrm{g} / \mathrm{mol})$

(Susilowati dan Harjani, 2013: 228)

\section{SIMPULAN}

Berdasarkan hasil penelitian yang diperoleh, maka dapat disimpulkan bahwa Label konsep keseluruhan yang dianalisis berjumlah 53 label konsep. Label konsep yang sama terdapat pada buku teks A maupun buku teks B berjumlah 22 label konsep yang sesuai dengan kurikulum 2013. Label konsep yang sesuai dengan kurikulum 2013 yang hanya terdapat pada buku teks A dan buku teks B masing-masing berjumlah 15 label konsep dan 13 label konsep.

Struktur makro wacana pada buku teks A pembahasan konsep pada dimensi elaborasi mencapai level 5 dan dimensi progresi pada level 2 terdapat 6 konsep. Struktur makro wacana pada buku teks B pembahasan konsep pada dimensi elaborasi mencapai level 6 dan dimensi progresi pada level 2 terdapat 4 konsep.

Proposisi yang berpotensi kesalahan konsep pada buku teks A, yaitu perubahan entalpi peruraian standar $\left(\Delta H_{\mathrm{d}}^{\circ}\right)$ dan perubahan entalpi pembakaran standar $\left(\Delta H_{\mathrm{c}}^{\circ}\right)$ dalam contoh soal berupa penulisan notasi, penentuan perubahan entalpi menggunakan kalorimeter dalam contoh soal berupa penulisan satuan, hukum Hess dalam contoh soal berupa penulisan untuk keterangan dalam menjawab soal, penentuan perubahan entalpi menggunakan entalpi pembentukan dalam contoh soal berupa kata yang digunakan untuk rumus kurang tepat, energi ikatan rata-rata dari segi bahasa yang digunakan, dan contoh soal energi ikatan yang tidak menuliskan satuan. Proposisi yang berpotensi kesalahan konsep pada buku teks B, yaitu jenis-jenis sistem dari segi bahasa yang digunakan dan contoh soal yang tidak memuat rumus terlebih dahulu serta tidak mencantumkan satuan pada konsep perubahan entalpi pembentukan standar, perubahan entalpi penguraian standar, perubahan entalpi pembakaran standar, perhitungan kalor, perubahan entalpi reaksi, perubahan entalpi menggunakan data energi ikatan.

\section{DAFTAR PUSTAKA}

Agustin, Dewi. 2017. Kesulitan Siswa Kelas XI IPA SMA Negeri Kota Palangka Raya Tahun Ajaran 2016/2017 dalam Memahami Penentuan Perubahan Entalpi dari Hukum Hess. Skripsi Sarjana, tidak diterbitkan, Universitas Palangka Raya. 
Arifin, Mulyati. 2007. Pengembangan Kurikulum dan Pembelajaran Kimia. Jakarta: Universitas Terbuka.

Arifin. 2008. Pembuatan Hiperteks Akademik pada Materi Kajian Kecepatan Reaksi dan Pemanfaatannya Sebagai Media Pembelajaran Kimia di SMA. Palangka Raya: Universitas Palangka Raya.

Arikunto, S. 2010. Prosedur Penelitian suatu Pendekatan Praktik. Jakarta: PT. Rineka Cipta.

Asi, N.B. 2018. Dimensi Pengetahuan Dan Tingkat Berpikir Pada Pembelajaran Kimia. Jurnal Ilmiah Kanderang Tingang. 9, 2 (Des. 2018), 103-113.

Atkins, P. W. 1994. Kimia Fisika, Jilid 1, Edisi Keempat. Bandung: Erlangga.

Berg, Van Den E, (Ed). 1991. Miskonsepsi Fisika dan Remediasi. Salatiga: Universitas Kristen Satya Wacana.

Bowyer, Gabriel. 2009. Teacher's handbook of Chemistry. Delhi: Global Media.

Dahar. R.W. 2006. Teori-Teori Belajar dan Pembelajaran. Jakarta: Erlangga.

Herlanti, Yanti. 2011. Trend Evaluasi Pembelajaran IPA Masa Kini dan Masa Depan. Seminar Nasional Pendidikan IPA Tahun 2011. Jakarta: UIN Syarif Hidayatullah.

Keenan C.W., dkk. 1984. Kimia untuk Universitas. Jakarta: Erlangga.

Kuswana, W.S. 2012. Taksonomi Kognitif (Perkembangan Ragam Berpikir). Bandung: PT Remaja Rosdakarya.

Majid, Abdul., dan Chaerul R. 2014. Pendekatan Ilmiah dalam Implementasi Kurikulum 2013. Bandung: PT. Remaja Rosdakarya.

Mulyanti, S. 2015. Kimia Dasar (Jilid 1). Bandung: Alfabeta.

Nurul, G. 2013. Menyiapkan Bahan Ajar Sesuai dengan Tingkat Berpikir Siswa. Kompasiana [online]. Tersedia: http://www.kompasiana.com.

Permendiknas Nomor 11 Tahun 2005 Tentang Buku Teks Pelajaran.

Priyambodo, E., Waldjinah, Anis D.R., dan Erna T.W. 2016. Buku Siswa Kimia untuk SMA/MA Kelas XI. Klaten: PT. Intan Pariwara.

Renkema, J. 2004. Introduction to Discourse Practice. Philadelphia: John Benjamins Publishing Company. 
Rohman, I., Mulyani, S. 2000. Kimia Fisika I, Pengantar Termodinamika dan Aplikasinya dalam Kimia. Bandung: Universitas Pendidikan Indonesia.

Sarungu, A.C. 2016. Kesulitan Memahami Konsep Perubahan Entalpi ( $\Delta H)$ Berdasarkan Energi Ikatan Rata-Rata pada Siswa Kelas XI IPA SMAN Sampit Tahun Ajaran 2015/ 2016. Skripsi Sarjana, tidak diterbitkan, Universitas Palangka Raya.

Siregar, N. 1994. Studi Penerapan Pedagogi Materi Subyek dalam Penulisan Buku Teks MIPA untuk Mengembangkan Keterampilan Intelektual Mahasiswa IKIP Bandung. Bandung: FPMIPA IKIP.

Sudarmo, U., dan Nanik M. 2014. Buku Siswa Kimia untuk SMA/ MA Kelas XI. Surakarta: Erlangga.

Sugiyo, Aprivianti. 2017. Sirok Bastra. Jurnal Ilmiah Kebahasaan dan Kesastraan, 5(01), ISSN 2354-7200.

Sukmadinata, N. S., dan Erliana, S. 2012. Kurikulum \& Pembelajaran Kompetensi. Bandung: PT Refika Aditama.

Suparno, P. 2005. Miskonsepsi dan Perubahan Konsep dalam Pendidikan Fisika. Jakarta: Grasindo.

Taluka, Melvie. 2013. Penerapan Model Pembelajaran Berorientasi Perubahan Konseptual Berbantuan Virtual Laboratory untuk Meningkatkan Pemahaman Konsep IPA Mahasiswa Calon Guru SD. Bandung: Universitas Pendidikan Indonesia.

Tarigan, H Guntur. 1986. Membaca Sebagai Suatu Keterampilan Berbahasa. Bandung: Angkasa.

Vitriani, I.R. 2012. Analisis Wacana Sistem Ekskresi. Bandung: Universitas Pendidikan Indonesia.

Wiguna, F.M. 2014. Kajian Teoritik Tahap Strukturisasi Pengolahan Bahan Ajar 4S TMD Dilihat dari Aspek Filosopis, Aspek Psikologi, Aspek Didaktis dan Aplikasinya Pada Pokok Larutan Asam Basa. Bandung: Universitas Pendidikan Indonesia. 